\title{
Effects of $\beta$-Lipotropin and $\beta$-Lipotropin-derived Peptides on Aldosterone Production in the Rat Adrenal Gland
}

\author{
Hiroaki Matsuoka, Patrick J. Mulrow, and Roberto Franco-Saenz, \\ Department of Medicine, Medical College of Ohio, Toledo, Ohio 43699 \\ Снон Hao LI, Hormone Research Laboratory, University of California, \\ San Francisco, California 94143
}

\begin{abstract}
A B S T RAC T To investigate the role of non-ACTH pituitary peptides on steroidogenesis, we studied the effects of synthetic $\beta$-lipotropin, $\beta$-melanotropin, and $\beta$-endorphin on aldosterone and corticosterone stimulation using rat adrenal collagenase-dispersed capsular and decapsular cells. $\beta$-lipotropin induced a significant aldosterone stimulation in a dose-dependent fashion $(10 \mathrm{nM}-1 \mu \mathrm{M})$. $\beta$-endorphin, which is the carboxyterminal fragment of $\beta$-lipotropin, did not stimulate aldosterone production at the doses used $(3 \mathrm{nM}-6 \mu \mathrm{M})$. $\beta$-melanotropin, which is the middle fragment of $\beta$ lipotropin, showed comparable effects on aldosterone stimulation. $\beta$-lipotropin and $\beta$-melanotropin did not affect corticosterone production in decapsular cells. Although ACTH $^{1-24}$ caused a significant increase in cyclic AMP production in capsular cells in a dosedependent fashion ( $1 \mathrm{nM}-1 \mu \mathrm{M}), \beta$-lipotropin and $\beta$-melanotropin did not induce an increase in cyclic AMP production at the doses used $(1 \mathrm{nM}-1 \mu \mathrm{M})$. The $\beta$-melanotropin analogue (glycine[Gly ${ }^{10}-\beta$-melanotropin) inhibited aldosterone production induced by $\beta$ lipotropin or $\beta$-melanotropin, but did not inhibit aldosterone production induced by $\mathrm{ACTH}^{1-24}$ or angiotensin II. Corticotropin-inhibiting peptide (ACTH ${ }^{7-38}$ ) inhibited not only ACTH ${ }^{1-24}$ action but also $\beta$-lipotropin or $\beta$-melanotropin action; however it did not affect angiotensin II-induced aldosterone production. (saralasin [Sar] ${ }^{1}$; alanine [Ala $\left.{ }^{8}\right)$-Angiotensin II inhibited the actions of $\beta$-lipotropin and $\beta$-melanotropin as well as angiotensin II. These results indicate that $(a) \beta$ lipotropin and $\beta$-melanotropin cause a significant stimulation of aldosterone production in capsular cells, (b) $\beta$-lipotropin and $\beta$-melanotropin have a preferential effect on zona glomerulosa cells, (c) $\beta$-melanotropin
\end{abstract}

\footnotetext{
Dr. Matsuoka's present address is the University of Tokyo, Hongo, Bunkyo-ku, Tokyo 113, Japan.

Received for publication 4 December 1980 and in revised form 20 April 1981.
}

contains the active peptide core necessary for aldosterone stimulation, $(d)$ the effects of these peptides on aldosterone production may be independent of cyclic AMP, and (e) the receptors for $\beta$-lipotropin or $\beta$-melanotropin may be different from those for ACTH or angiotensin II.

\section{INTRODUCTION}

Although it is well recognized that ACTH and angiotensin II have a potent aldosterone-stimulating effect, experimental evidence suggests that a non-ACTH pituitary factor(s) is important in the aldosterone response during sodium restriction $(1,2)$. Also, clinical evidence indicates the presence of an unknown aldosterone stimulator $(3,4)$. Very recently we reported that $\beta$-lipotropin induced aldosterone stimulation in rat adrenal capsular cells (5). In this study the mechanism of aldosterone-stimulating action of $\beta$-lipotropin was investigated. Also, because $\beta$-lipotropin has the complete amino acid sequence of $\beta$-melanotropin and $\beta$-endorphin (6-8), we investigated the effects of these $\beta$-lipotropin-derived peptides on steroidogenesis using rat adrenal collagenase-treated capsular and decapsular cells.

\section{METHODS}

Materials. Ovine $\beta$-lipotropin $(\beta$-LPH $),{ }^{1}$ camel $\beta$-melanotropin $(\beta-\mathrm{MSH}), \beta-\mathrm{MSH}$ analogue ([Gly $\left.\left.{ }^{10}\right]-\beta-\mathrm{MSH}\right)$, and corticotropin-inhibiting peptide (ACTH ${ }^{7-38}$; CIP) were synthesized according to reported methods (9-12). ACTH ${ }^{1-24}$ was provided from Ciba-Geigy Corp. (Summit, N. J.), synthetic human $\beta$-endorphin and synthetic methionine (Met)and leucine (Leu)-enkephalin were purchased from Boehringer Mannheim Biochemicals (Indianapolis, Ind.), synthetic (aspartic acid [Asp] ${ }^{1}$; isoleucine [Ile] ${ }^{5}$ ) angiotensin II

\footnotetext{
${ }^{1}$ Abbreviations used in this paper: AII, angiotensin II; $\beta$-LPH, $\beta$-lipotropin; $\beta$-MSH, $\beta$-melanotropin; CIP, corticotropin-inhibiting peptide.
} 
(AII) and bovine serum albumin were obtained from Sigma Chemical Co. (St. Louis, Mo.), and synthetic (Sar ${ }^{1}, \mathrm{Ala}^{8}$ ) angiotensin II (Saralasin) was from Calbiochem-Behring Corp. (San Diego, Calif.). Collagenase was from Worthington Biochemical Corp. (Freehold, N. J.). 1-Methyl-3-isobutylxanthine was from Aldrich Chemical Co. (Milwaukee, Wis.). Medium 199 was from Gibco Laboratories (Grand Island Biological Co., Grand Island, N. Y.).

Preparations of adrenal capsular and decapsular cells. 20 Sprague-Dawley female rats $(180-220 \mathrm{~g})$ were used in each experiment. The rats were maintained on a regular Purina rat chow diet (Ralston Purina Co., St. Louis, Mo.) for at least 2 wk. The rats were killed by decapitation and the adrenal glands were removed and separated into the capsular and the decapsular portions according to reported methods (13). Each portion was incubated with $2 \mathrm{mg} / \mathrm{ml}$ collagenase and dispersed with a pasteur pipette. Collagenase-dispersed capsular (mainly zona glomerulosa cells) and decapsular (zona fasciculata and reticularis cells) adrenal cells were used for the experiments.

Stimulation of steroidogenesis. The capsular and decapsular cell suspensions (average cell counts: 100,000/tube) were incubated in duplicate in $1 \mathrm{ml}$ of Medium 199 containing $2 \mathrm{mg} / \mathrm{ml}$ bovine serum albumin with various amounts $(10 \mathrm{pM}-3 \mu \mathrm{M})$ of synthetic $\beta$-LPH, $\beta$-MSH, $\beta$-endorphin, Met- and Leu-enkephalin, ACTH ${ }^{1-24}$, and AII for $2 \mathrm{~h}$ at $37^{\circ} \mathrm{C}$ under $95 \% \mathrm{O}_{2}$ and $5 \% \mathrm{CO}_{2}$.

Cyclic AMP stimulation. To define the mechanism of aldosterone production by $\beta$-LPH-derived peptides, the capsular cell suspensions were incubted in duplicate in $1 \mathrm{ml}$ of Medium 199 containing $0.2 \mathrm{mM}$ 1-methyl-3-isobutylxanthine with various amounts $(1 \mathrm{nM}-1 \mu \mathrm{M})$ of $\beta$-LPH, $\beta$-MSH, ACTH ${ }^{1-24}$, and AII for $1 \mathrm{~h}$ at $37^{\circ} \mathrm{C}$. After incubation, $700 \mu \mathrm{l}$ of cell suspensions was transferred into glass tubes containing $300 \mu \mathrm{l}$ of $2 \mathrm{mM}$ theophylline and boiled in a water bath for $10 \mathrm{~min}$ as described (14).

Competitive inhibition studies. To answer the question of whether $\beta$-LPH and $\beta$-MSH have their own distinct receptors or not, the inhibition of aldosterone response to $\beta$-LPH, $\beta$-MSH, ACTH, ${ }^{1-24}$ and AII by the $\beta$-MSH analogue, CIP, and Saralasin was examined. The capsular cell suspensions were preincubated with various amounts $(0.1 \mathrm{nM}-$ $30 \mu \mathrm{M})$ of $\beta$-MSH analogue, CIP, or Saralasin for $5 \mathrm{~min}$ and were then incubated with submaximal amounts of $\beta$-LPH and $\beta$-MSH $(30 \mathrm{nM})$ and $\mathrm{ACTH}^{1-24}$ and AII $(1.5 \times 0.1 \mathrm{nM})$ for $2 \mathrm{~h}$ at $37^{\circ} \mathrm{C}$.

Measurement of aldosterone, corticosterone, and cyclic $A M P$. Aldosterone in the incubation medium was measured by a direct radioimmunoassay as described $(13,15)$. The aldosterone value measured directly was well correlated with the value obtained after LH-20 column separation. $(y=1.1 \times+3.5, r=0.99, P<0.001, n=18)$. Corticosterone was also measured directly by radioimmunoassay using a highly specific antibody from Endocrine Science (Tarzana, Calif.). Cyclic AMP was measured by protein-binding assay using a kit from Amersham (Arlington Heights, Ill.) as described $(16,17)$. The interassay coefficients of variations for the aldosterone, corticosterone, and cyclic AMP assays were $10.0 \%(n=12), 9.0 \% \quad(n=16)$, and $11.3 \% \quad(n=10)$, respectively. The intra-assay coefficients of variations for the aldosterone, corticosterone, and cyclic AMP assays were $6.3 \%$ $(n=16), 7.5 \%(n=16)$, and $6.6 \%(n=9)$, respectively. The recoveries of aldosterone and corticosterone added to the incubation medium were $98.5 \pm 2.1 \%$ (SE) $(n=14)$ and $91.6 \pm 1.5 \%(n=16)$, respectively. The recovery of cyclic AMP added to the cell suspension before boiling was $98.1 \pm 1.5 \%(n=9)$. Statistical analysis was performed using the paired $t$ test. A $P$ value of $<0.05$ was considered significant.

\section{RESULTS}

Effects of $\beta$-LPH-derived peptides, ACTH ${ }^{1-24}$, and AII on steroidogenesis. Significant increases in aldosterone production were produced by $0.1 \mathrm{nM} \mathrm{ACTH}^{1-24}$ or AII, and maximum increases were obtained with $10 \mathrm{nM} \mathrm{ACTH}{ }^{1-24}$ or AII in capsular cells. $\beta$-LPH (10 $\mathrm{nM}$ ) caused a significant increase in aldosterone production (from the control value of $33.7 \pm 1.8$ (SE) to $47.6 \pm 6.2 \mathrm{ng} / 100,000$ capsular cells, $P<0.05$ ). Maximal aldosterone response was obtained with $3 \times 0.1$ $\mu \mathrm{M} \beta$-LPH $(117.3 \pm 9.3 \mathrm{ng} / 100,000$ capsular cells), and the aldosterone level obtained with maximum doses of $\beta$-LPH was similar to the one obtained with maximum doses of AII (Fig. 1). $\beta$-LPH and $\beta$-MSH caused significant stimulation of aldosterone, and their effects are comparable (Fig. 2). $\beta$-endorphin and Met- and Leuenkephalin (data not shown) did not increase aldosterone production. Whereas $\mathrm{ACTH}^{1-24}$ has similar effects on capsular and decapsular cells, $\beta$-LPH and $\beta$-MSH did not affect corticosterone production at the doses used in decapsular cells (Fig. 3). Neither AII nor $\beta$-endorphin stimulated corticosterone production in decapsular cells (Fig. 3).

Effects of $\beta$-LPH-derived peptides, ACTH ${ }^{1-24}$, and AII on cyclic AMP production. Although ACTH ${ }^{1-24}$

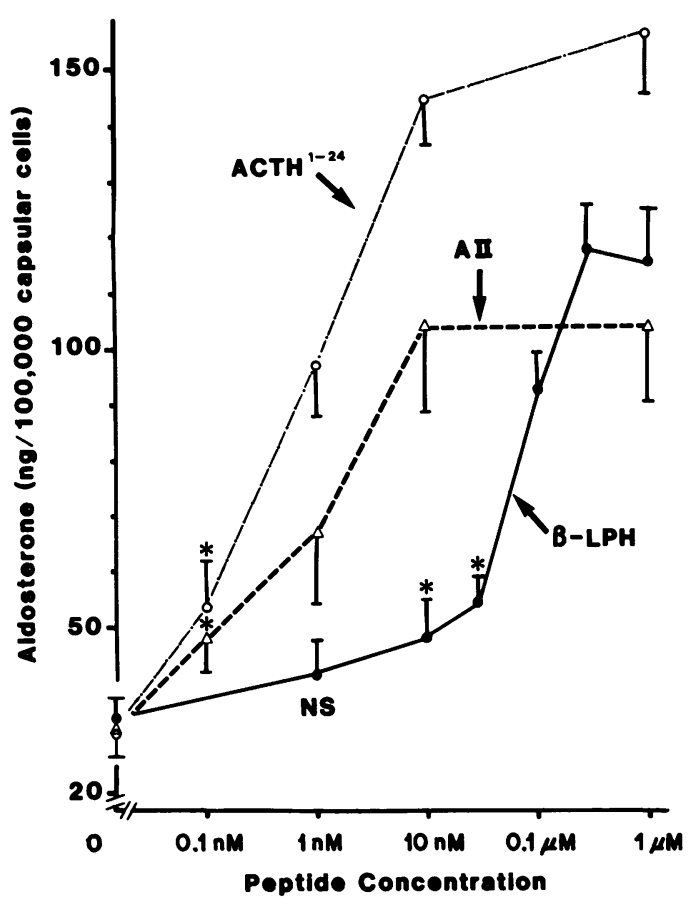

Figure 1 Effects of ACTH ${ }^{1-24}$, AII, and $\beta$-LPH on aldosterone production in capsular cells. Each point represents mean \pm SE from four different experiments. NS, not significantly different from the control value; ${ }^{*}$, significantly different from the control value $(P<0.05)$. All other points significantly different from the control value $(P<0.01)$. 


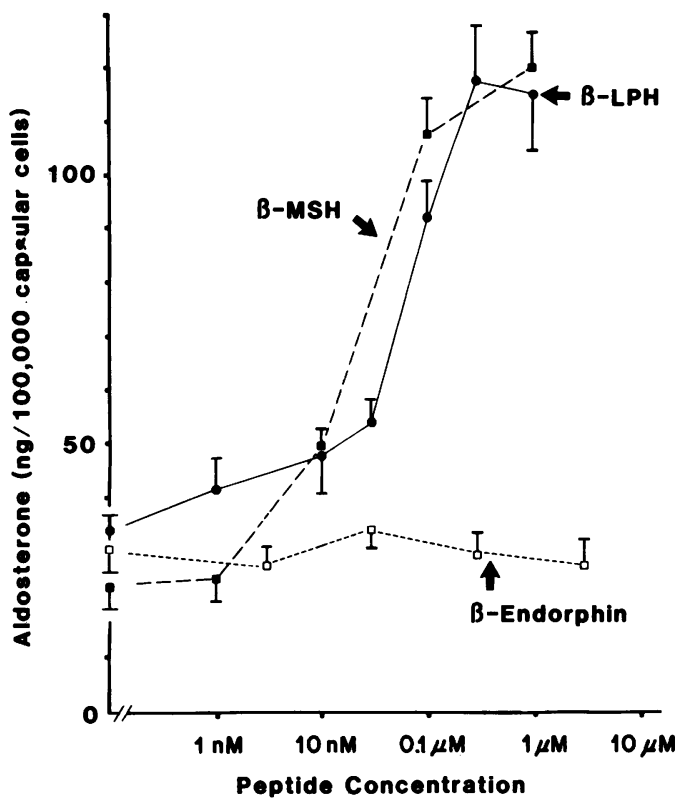

FIGURE 2 Effects of $\beta$-LPH-derived peptides on aldosterone production in capsular cells. Each point represents mean $\pm \mathrm{SE}$ from three or four different experiments.

caused a significant cyclic AMP production in a dosedependent fashion, $\beta$-LPH-derived peptides and AII at the doses used did not stimulate cyclic AMP production (Fig. 4). This failure to stimulate cyclic AMP was present even at doses of $\beta-\mathrm{LPH}$ and $\beta-\mathrm{MSH}$

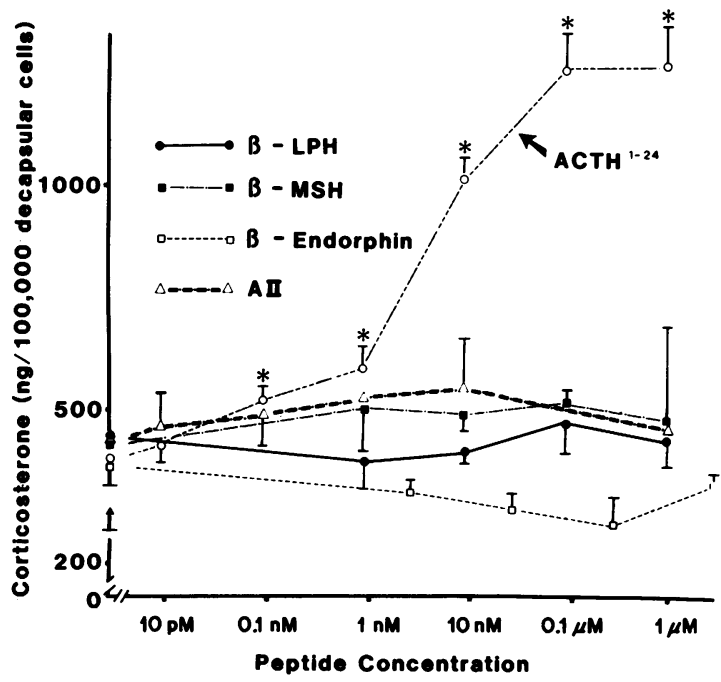

Figure 3 Effects of ACTH ${ }^{1-24}$, AII, and $\beta$-LPH-derived peptides on corticosterone production in decapsular cells. Each point represents mean $\pm S E$ from three different experiments. *, significantly different from the control value $(P<0.01)$. All other points not significantly different from the control value.

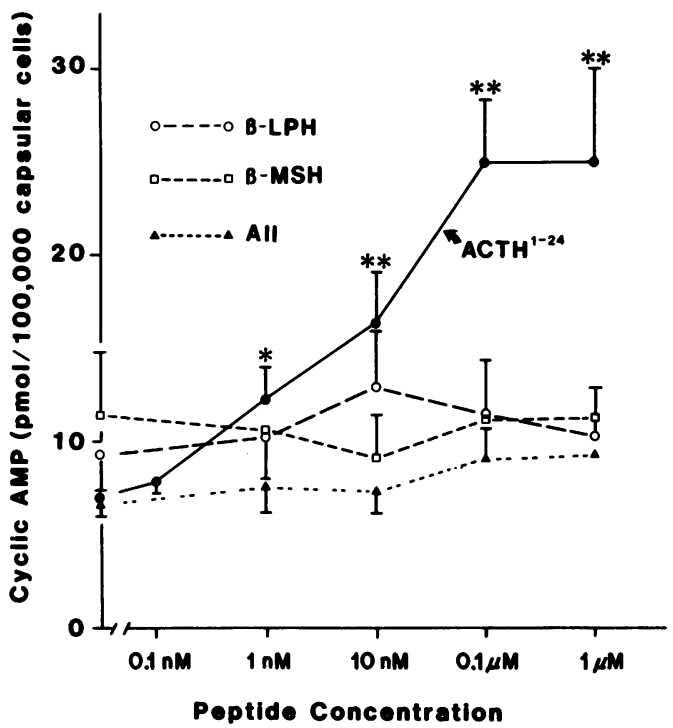

FIGURE 4 Effects of ACTH ${ }^{1-24}, \beta$-LPH, $\beta$-MSH, and AII on cyclic AMP production in capsular cells. Each point represents mean $\pm S E$ from three or four different experiments, *, **; significantly different from the control value $(P<0.05$ and $P<0.01$, respectively). All other points not significantly different from the control value.

(1 $\mu \mathrm{M}$ ) that were larger than the doses required to stimulate aldosterone maximally (Figs. 2 and 4 ). The dose of ACTH that stimulated aldosterone maximally $(10 \mathrm{nM})$ doubled cyclic AMP production and the next higher dose $(0.1 \mu \mathrm{M})$ tripled cyclic AMP production. Therefore, the pattern of cyclic AMP response to $\beta$-LPH and $\beta$-MSH is different from the pattern after ACTH and similar to the pattern after AII.

Inhibition of aldosterone production by $\beta-M S H$ analogue, CIP, or Saralasin. The effects of the $\beta-\mathrm{MSH}$ analogue on the aldosterone responses to submaximal-stimulating doses of $\beta$-LPH or $\beta$-MSH $(30 \mathrm{nM}$ ) and of $\mathrm{ACTH}^{1-24}$ or AII $(0.15 \mathrm{nM})$ are shown in Fig. 5. These doses of peptides gave comparable increases in aldosterone production, yet the production rates were still submaximal (Tables I, II). The $\beta$-MSH analogue was a potent inhibitor of aldosterone production induced by $\beta$-LPH and $\beta$-MSH, causing $\sim 30 \%$ inhibition at a molar ratio of $100: 1$ and $\sim 80 \%$ inhibition at a molar ratio of 1,000:1. The $\beta$-MSH analogue, however, did not affect ACTH ${ }^{1-24}$ or AII-induced aldosterone production at molar ratios from 10:1 to 10,000:1. On the other hand, CIP inhibited aldosterone production induced not only by ACTH ${ }^{1-24}$ but also by $\beta$-LPH or $\beta$-MSH (Fig. 6, Table II). In one experiment a large dose of $\beta$-LPH $(1 \mu \mathrm{M})$ was used. CIP, in molar ratios of $1: 1$ and 10:1, inhibited the aldosterone response by 20 and $25 \%$, respectively. The control aldosterone production was $26.5 \mathrm{ng} / 10^{5}$ adrenal cells, and rose to $146 \mathrm{ng} / 10^{5}$ cells with $1 \mu \mathrm{M} \beta$-LPH. CIP at 


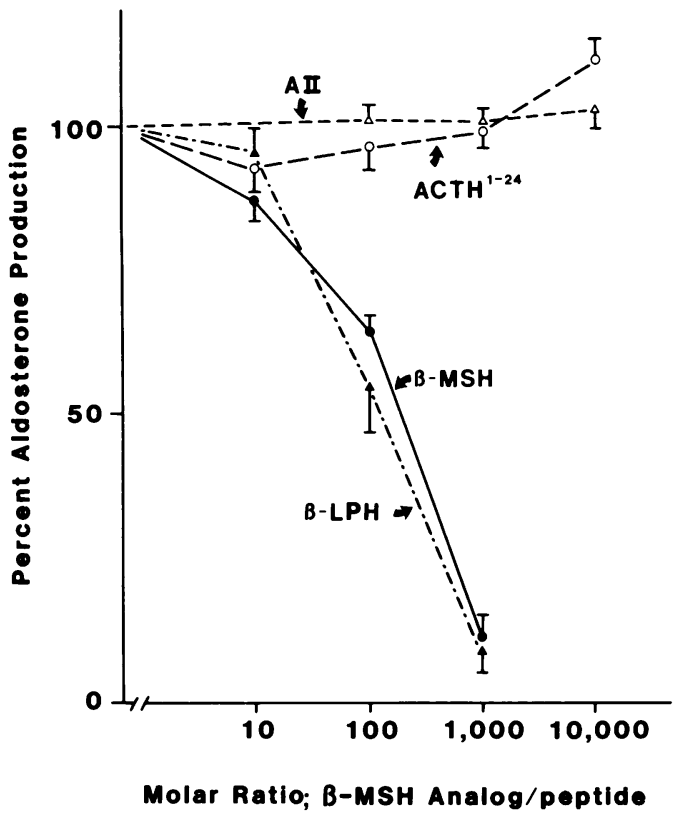

Figure 5 Inhibition of aldosterone responses to submaximal stimulating doses of $\beta$-LPH and $\beta$-MSH $(30 \mathrm{nM})$, and $\mathrm{ACTH}^{1-24}$ and AII $(0.15 \mathrm{nM})$ by various concentrations of $\beta$-MSH analogue. Each point represents mean $\pm S E$ from three different experiments.

$1 \mu \mathrm{M}$ reduced the response to $122 \mathrm{ng}$ and at $10 \mu \mathrm{M}$ reduced the response to $102 \mathrm{ng}$. Although ACTH at $10 \mathrm{nM}$ caused a similar aldosterone response (145 ng), CIP at molar ratios of $1: 1$ and 10:1 had no inhibitory effect. It would appear, therefore, that $\beta$-LPH is more sensitive to the inhibitory action of CIP than is ACTH. CIP, however, did not inhibit aldosterone production induced by AII. Also, Saralasin inhibited not only the AII-induced aldosterone production but also the $\beta$ $\mathrm{LPH}$ - and $\beta$-MSH-induced aldosterone production. However, this analogue did not affect aldosterone production induced by $\mathrm{ACTH}^{1-24}$ (Fig. 7). The $\beta$-MSH analogue, CIP, and Saralasin had no significant aldosterone-stimulating activity in capsular cells at doses from $1 \mathrm{nM}$ to $30 \mu \mathrm{M}$ (unpublished data).

\section{DISCUSSION}

There is considerable evidence indicating that the regulation of aldosterone secretion cannot be completely explained by the known stimulators. Palmore and Mulrow (1) and McCaa et al. (2) have reported that a non-ACTH pituitary factor(s) is essential for the aldosterone response during sodium restriction in rats and dogs. Recently, Sen et al. (18) reported the isolation of a glycoprotein from normal human urine that produced hypertension associated with high plasma aldosterone values in the rat. Removal of some carbohydrate moieties with neurominadase increased the activity of this protein on aldosterone production in vitro (19). In view of these reports, we have examined the effects of $\beta$-LPH-derived peptides on steroidogenesis using rat adrenal glands. Although $\beta$ - LPH is derived from a common pro-ACTH/ $\beta$ - LPHglycosylated precursor molecule present in the pituitary gland $(6,7)$, its physiological role remains unclear. $\beta$-LPH (1-91 amino acids) contains within it the entire amino acid sequence of $\beta$-MSH $\left(\beta-\mathrm{LPH}^{41-58}\right)$ $(6,8)$. In our studies $\beta$-LPH and $\beta$-MSH have a significant aldosterone-stimulating effect and similar to AII have a preferential effect on the zona glomerulosa cells. Because $\beta$-endorphin $\left(\beta-\mathrm{LPH}^{61-91}\right)$ has no steroidogenic property, the significant portion of the active peptide core necessary for aldosterone stimulation is included in $\beta$-MSH. $\beta$-MSH contains the heptapeptide sequence (Met-glutamic acid(Glu)-histidine(His)-phenylalanine(Phe)-arginine(Arg)-tryptophan-(Trp)glycine(Gly)) common to ACTH, and $\beta$-LPH which may be the peptide core required for aldosterone stimulation. Previous studies suggest that $\beta$-MSH has only weak steroidogenic potency on the adrenal gland in the rat $(20,21)$. However, in those studies aldosterone production was not examined. It has been re-

TABLE I

Inhibition of Aldosterone Production by $\beta$-MSH Analogue

\begin{tabular}{|c|c|c|c|}
\hline \multirow[b]{2}{*}{$\beta$-LPH } & \multirow[t]{2}{*}{$\begin{array}{c}\beta \text {-MSH } \\
\text { analogue }\end{array}$} & \multicolumn{2}{|c|}{ Aldosterone } \\
\hline & & ng/100,000 cells & Inhibition \% \\
\hline$(-)$ & $(-)$ & $30.0 \pm 3.7$ & \\
\hline $30 \mathrm{nM}$ & $(-)$ & $53.3 \pm 6.8$ & \\
\hline $30 \mathrm{nM}$ & $0.3 \mu \mathrm{M}$ & $52.3 \pm 7.9$ & 4.3 \\
\hline $30 \mathrm{nM}$ & $3 \mu \mathrm{M}$ & $42.8 \pm 8.0$ & 45.1 \\
\hline $30 \mathrm{nM}$ & $30 \mu \mathrm{M}$ & $32.1 \pm 5.8$ & 91.0 \\
\hline \multicolumn{4}{|l|}{$\beta$-MSH } \\
\hline$(-)$ & $(-)$ & $25.2 \pm 3.8$ & \\
\hline $30 \mathrm{nM}$ & $(-)$ & $67.5 \pm 7.2$ & \\
\hline $30 \mathrm{nM}$ & $0.3 \mu \mathrm{M}$ & $62.3 \pm 3.1$ & 12.3 \\
\hline $30 \mathrm{nM}$ & $3 \mu \mathrm{M}$ & $52.7 \pm 3.8$ & 35.0 \\
\hline $30 \mathrm{nM}$ & $30 \mu \mathrm{M}$ & $30.2 \pm 4.5$ & 88.2 \\
\hline \multicolumn{4}{|l|}{$\mathrm{ACT}^{1-24}$} \\
\hline$(-)$ & $(-)$ & $31.0 \pm 3.1$ & \\
\hline $0.15 \mathrm{nM}$ & $(-)$ & $76.5 \pm 3.1$ & \\
\hline $0.15 \mathrm{nM}$ & $1.5 \mathrm{nM}$ & $73.3 \pm 4.0$ & 7.0 \\
\hline $0.15 \mathrm{nM}$ & $15 \mathrm{nM}$ & $74.8 \pm 4.9$ & 3.7 \\
\hline $0.15 \mathrm{nM}$ & $0.15 \mu \mathrm{M}$ & $76.1 \pm 4.3$ & 0.9 \\
\hline $0.15 \mathrm{nM}$ & $1.5 \mu \mathrm{M}$ & $82.1 \pm 2.9$ & -12.3 \\
\hline \multicolumn{4}{|l|}{ AII } \\
\hline$(-)$ & $(-)$ & $32.5 \pm 2.1$ & \\
\hline $0.15 \mathrm{nM}$ & $(-)$ & $80.2 \pm 7.3$ & \\
\hline $0.15 \mathrm{nM}$ & $15 \mathrm{nM}$ & $81.1 \pm 7.9$ & -1.9 \\
\hline $0.15 \mathrm{nM}$ & $0.15 \mu \mathrm{M}$ & $80.5 \pm 7.9$ & -0.6 \\
\hline $0.15 \mathrm{nM}$ & $1.5 \mu \mathrm{M}$ & $81.8 \pm 7.3$ & -3.4 \\
\hline
\end{tabular}


TABLE II

Inhibition of Aldosterone Production by CIP

\begin{tabular}{|c|c|c|c|}
\hline & \multirow[t]{2}{*}{ CIP } & \multicolumn{2}{|c|}{ Aldosterone } \\
\hline & & ng/100,000 cells & Inhibition \% \\
\hline \multicolumn{4}{|l|}{$\mathrm{ACTH}^{1-24}$} \\
\hline$(-)$ & $(-)$ & $26.0 \pm 1.7$ & \\
\hline $0.15 \mathrm{nM}$ & $(-)$ & $64.9 \pm 4.9$ & \\
\hline $0.15 \mathrm{nM}$ & $15 \mathrm{nM}$ & $63.5 \pm 5.8$ & 3.6 \\
\hline $0.15 \mathrm{nM}$ & $0.15 \mu \mathrm{M}$ & $59.0 \pm 5.3$ & 15.2 \\
\hline $0.15 \mathrm{nM}$ & $1.5 \mu \mathrm{M}$ & $33.8 \pm 2.4$ & 79.9 \\
\hline \multicolumn{4}{|l|}{ AII } \\
\hline$(-)$ & $(-)$ & $31.7 \pm 1.0$ & \\
\hline $0.15 \mathrm{nM}$ & $(-)$ & $54.8 \pm 1.0$ & \\
\hline $0.15 \mathrm{nM}$ & $15 \mathrm{nM}$ & $52.6 \pm 1.4$ & 9.5 \\
\hline $0.15 \mathrm{nM}$ & $0.15 \mu \mathrm{M}$ & $53.6 \pm 1.1$ & 5.2 \\
\hline $0.15 \mathrm{nM}$ & $1.5 \mu \mathrm{M}$ & $54.6 \pm 1.3$ & 0.9 \\
\hline $0.15 \mathrm{nM}$ & $15 \mu \mathrm{M}$ & $55.6 \pm 1.2$ & -3.5 \\
\hline \multicolumn{4}{|l|}{$\beta$-LPH } \\
\hline$(-)$ & $(-)$ & $27.6 \pm 2.2$ & \\
\hline $30 \mathrm{nM}$ & $(-)$ & $56.0 \pm 2.9$ & \\
\hline $30 \mathrm{nM}$ & $3 \mu \mathrm{M}$ & $50.2 \pm 2.8$ & 20.4 \\
\hline $30 \mathrm{nM}$ & $30 \mu \mathrm{M}$ & $43.2 \pm 1.9$ & 45.1 \\
\hline \multicolumn{4}{|l|}{$\beta$-MSH } \\
\hline$(-)$ & $(-)$ & $28.6 \pm 1.0$ & \\
\hline $30 \mathrm{nM}$ & $(-)$ & $82.5 \pm 1.5$ & \\
\hline $30 \mathrm{nM}$ & $3 \mu \mathrm{M}$ & $79.2 \pm 3.3$ & 6.1 \\
\hline $30 \mathrm{nM}$ & $30 \mu \mathrm{M}$ & $53.9 \pm 1.0$ & 53.1 \\
\hline
\end{tabular}

ported that human $\beta$-MSH may be a degradation product of $\beta$-LPH during extraction of plasma or pituitary gland and that in human plasma the immunoassayable $\beta$-MSH may be $\beta$-LPH $(22,23)$. In some species, however, the pars intermedia may be a main source of $\beta$-MSH (24). The secretion of ACTH and $\beta$-LPH or $\beta$-MSH occurs simultaneously in most instances. Several investigators, however, reported dissociation of ACTH and $\beta$-MSH (or $\beta$-LPH) secretion under some conditions (25-29). Interestingly, Howe and Thody (30) reported that changes in sodium balance induced changes in the content of MSH as well as histological changes in the pars intermedia of the rat. Also, Kobayashi and Takema (31) reported histological changes in the pars intermedia of mice during sodium restriction. Furthermore, Page et al. (32) demonstrated that the concomitant administration of $\alpha$-MSH and growth hormone stimulated aldosterone secretion in hypophysectomized sodium-depleted rats, while Vinson et al. (33) reported that $\alpha$-MSH stimulated aldosterone production by adrenal glomerulosa cells in vitro. A synthetic peptide, $\gamma_{3}-\mathrm{MSH}$, which represents a portion of the amino terminal or $16 \mathrm{~K}$ fragment within the pro-ACTH/ $\beta$-LPH precursor molecule, potentiates the stimulation of aldosterone production by ACTH

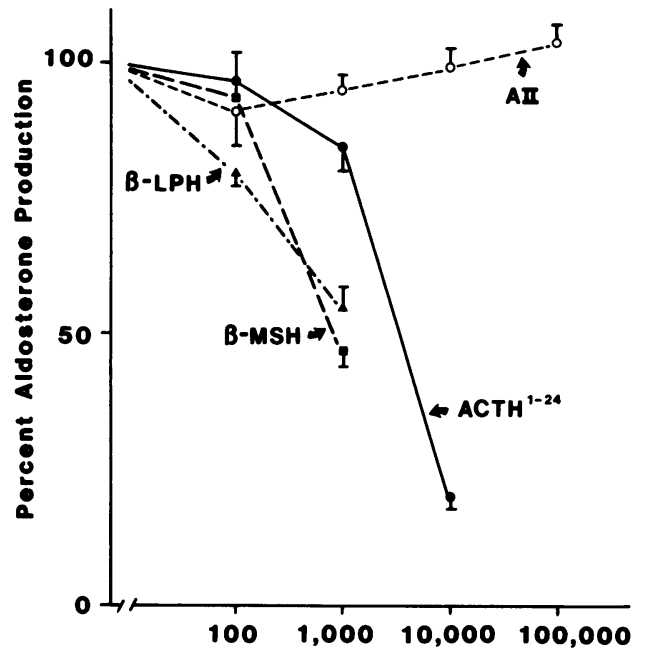

Molar Ratlo; CIP/peptide

FIGURE 6 Inhibition of aldosterone responses to submaximal stimulating doses of $\beta$-LPH and $\beta$-MSH $(30 \mathrm{nM})$, and ACTH $^{1-24}$ and AII $(0.15 \mathrm{nM})$ by various concentrations of CIP. Each point represents mean \pm SE from three different experiments.

in hypophysectomized rats (34). These authors speculate that the $\gamma-\mathrm{MSH}$ region of the $16 \mathrm{~K}$ fragment may play a role in control of steroidogenesis. These data suggest that $\beta$-MSH or other similar pituitary pep-

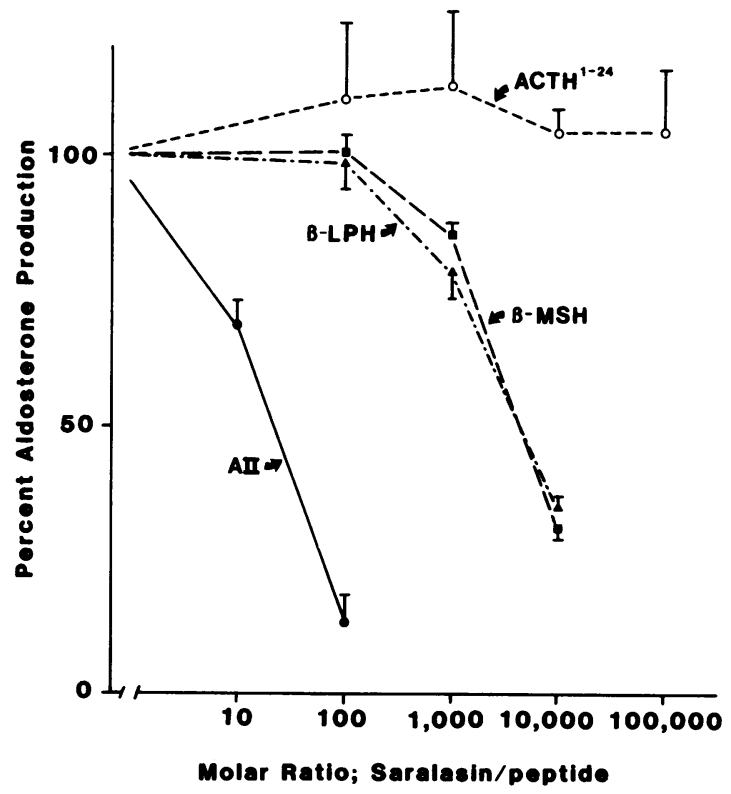

FIGURE 7 Inhibition of aldosterone responses to submaximal stimulating doses of $\beta$-LPH and $\beta$-MSH $(30 \mathrm{nM})$, and ACTH $^{1-24}$ and AII (0.15 $\left.\mathrm{nM}\right)$ by various concentrations of Saralasin. Each point represents mean $\pm S E$ from three different experiments. 
tides may be involved in the regulation of aldosterone secretion.

It has been shown that $\beta$-LPH increases the level of plasma aldosterone in the rat in vivo (35). In this study $\beta$-LPH and $\beta$-MSH have a preferential effect on the zona glomerulosa cells. These results raise the possibility that $\beta$-LPH or other pituitary peptides play a role in the regulation of aldosterone secretion. The relatively high doses needed to see an effect on aldosterone production militate against this possibility. In our studies, the smallest concentration of $\beta$-LPH that frequently stimulated aldosterone slightly (although not statistically significant) was $1 \mathrm{nM} /$ /iter. This concentration is $\sim 100$ times higher than the levels found in normal human peripheral plasma $(36,37)$. However, in patients with Nelson's syndrome ( $\sim 2$ $\times 1 \mathrm{nM})$ and Addison's disease $(\sim 2 \times 0.1 \mathrm{nM}), \beta-\mathrm{LPH}$ levels approach this concentration $(36,37)$. The plasma levels of $\beta$-LPH in conditions with hyperaldosteronism are unknown. Furthermore, in our study we investigated the effects of ovine $\beta$-LPH and camel $\beta$-MSH in the rat and compared their effects against $\mathrm{ACTH}{ }^{1-24}$, which is known to be the biologically active sequence of ACTH for all species. Species differences have been shown for the lipolytic effect of $\beta$-LPH $(38,39)$. Therefore it may be possible that species difference may exist in the aldosterone response to $\beta$-LPHderived peptides. It may also be possible that $\beta$-LPH or $\beta-\mathrm{MSH}$ is a component of a larger pituitary peptide which may be more potent in vitro or in vivo. Finally, the adrenal gland may well develop increased sensitivity to $\beta$-LPH under certain conditions, as it does to AII following sodium depletion and to ACTH in Cushing's disease.

To elucidate the mechanism of the aldosteronestimulating activity of $\beta-\mathrm{LPH}$ and $\beta-\mathrm{MSH}$, the cyclic AMP responses to $\mathrm{ACTH}^{1-24}$ and $\beta$-LPH-derived peptides were examined. The concept that cyclic AMP is the mediator of the steroidogenic action of ACTH on the adrenal gland has been supported by previous studies $(40,41)$. Fujita et al. (14) have reported that the action of ACTH on aldosterone secretion is mediated by cyclic AMP. In their study as well as in ours, the concentration of $\mathrm{ACTH}(1 \mathrm{nM})$ required to stimulate a significant cyclic AMP production is 10 times higher than that required to induce a significant aldosterone stimulation. $\beta$-LPH and $\beta$-MSH at the doses used stimulated aldosterone production without causing detectable changes in cyclic AMP production. In this respect, $\beta$-LPH and $\beta-M S H$ may act on aldosterone secretion through a mechanism similar to that of AII rather than of ACTH, because even maximum aldosterone-stimulating doses of $\beta$-LPH $(1 \mu \mathrm{M})$ did not increase cyclic AMP. Several investigators have suggested that only a small increase of cyclic AMP production is necessary to induce steroidogenesis
$(42,43)$. If this is the case, we cannot exclude the role of cyclic AMP in the aldosterone stimulation induced by $\beta$-LPH and $\beta$-MSH.

The $\beta$-MSH analogue inhibited aldosterone production induced by $\beta-\mathrm{LPH}$ or $\beta$-MSH to a similar degree. However, aldosterone production induced by $\mathrm{ACTH}^{1-24}$ or AII was not affected by the $\beta$-MSH analogue. These results suggest that the receptors for $\beta$-LPH are the same as those for $\beta$-MSH and may be different from those for ACTH or AII. It is known that CIP has a 32-amino acid sequence that corresponds to the $\mathrm{ACTH}^{7-38}$ sequence and is isolated from human pituitary glands (12). This peptide is devoid of corticosteroidogenic activity and causes a $50 \%$ inhibition of ACTH-induced corticosterone production by rat adrenal cells in vitro at a molar ratio of $\sim 10,000: 1$ (12). Our finding with respect to aldosterone inhibition is quite similar. In this study CIP inhibited not only ACTH but also $\beta$-LPH and $\beta$-MSH action and appears to be a more effective inhibitor of the latter peptides. CIP, however, did not inhibit AII action. These results suggest that there may be two kinds of binding sites for ACTH with different affinities, and one of these binding sites may be shared by $\beta$-LPH-derived peptides. Lefkowitz et al. (44) also proposed the existence of two kinds of binding sites for ACTH in a mouse adrenal cell tumor. As an alternative explanation, CIP may interact with the peptides and cause structural changes that modify binding to the receptor. It is proposed that a specific conformation of ACTH is necessary for receptor binding (45).

The effect of Saralasin on aldosterone production induced by $\beta$-LPH or $\beta$-MSH is difficult to explain. Saralasin inhibited AII, $\beta$-LPH, and $\beta$-MSH actions but did not affect ACTH action. One possible explanation would be that the receptor for $\beta$-LPH-derived peptides shares some binding properties with the AII and ACTH receptors. However, it is unlikely that $\beta$-LPH-derived peptides and AII share the same receptors, because their amino acid sequence are completely different. Another possibility is that high doses of Saralasin cause changes at the receptor level similar to those reported after the addition of guanylnucleotides (46). In our study CIP did not inhibit AII action, and Saralasin did not inhibit ACTH action. Therefore, it is unlikely that the effect of high doses of CIP and Saralasin is a toxic or nonspecific effect. Further studies are necessary to resolve these problems.

In conclusion $\beta$-LPH and $\beta$-MSH stimulate aldosterone production in capsular cells. In contrast to ACTH, $\beta$-LPH- and $\beta$-LPH-derived peptides do not affect cyclic AMP production in capsular cells and do not increase corticosterone production in decapsular cells, suggesting that the mechanism of action may be different from that of ACTH. These peptides may play a role in the regulation of aldosterone secretion. 


\section{ACKNOWLEDGMENT}

This work was supported in part by National Institutes of Health grant H1-19644 and grant GM-2907.

\section{REFERENCES}

1. Palmore, W. P., and P. J. Mulrow. 1967. Control of aldosterone secretion by the pituitary gland. Science (Wash., D. C.). 158: 1482-1484.

2. McCaa, R. E., D. B. Young, A. C. Guyton, and C. S. McCaa. 1974. Evidence for a role of an unidentified pituitary factor in regulating aldosterone secretion during altered sodium balance. Circ. Res. Suppl. 34-35: 15-25.

3. Davis, W. W., H. H. Newsome, L. D. Wright, Jr., W. G. Hammond, J. Easton, and F. C. Bartter. 1967. Bilateral adrenal hyperplasia as a cause of primary aldosteronism with hypertension, hypokalemia and suppressed renin activity. Am. J. Med. 42: 642-647.

4. Nicholls, M. G., E. A. Espiner, H. Hughes, J. Ross, and D. T. Stewart. 1975. Primary aldosteronism; a study in contrasts. Am. J. Med. 59: 334-342.

5. Matsuoka, H., P. J. Mulrow, and C. H. Li. 1980. $\beta$-lipotropin; a new aldosterone-stimulating factor. Science (Wash. D. C.). 209: 307-308.

6. Nakanishi, S., A. Inoue, T. Kita, M. Nakamura, A. C. Y. Chang, S. N. Cohen, and S. Numa. 1979. Nucleotide sequence of cloned cDNA for bovine corticotropin$\beta$-lipotropin precursor. Nature (Lond.). 278: 423-427.

7. Imura, H., and Y. Nakai. 1981. "Endorphins" in pituitary and other tissues. Annu. Rev. Physiol. 43: 265-278.

8. Li, C. H., L. Barnafi, M. Chretien, and D. Chung. 1965. Isolation and amino-acid sequence of $\beta$-LPH from sheep pituitary glands. Nature (Lond.). 208: 1093-1094.

9. Yamashiro, D., and C. H. Li. 1978. Total synthesis of ovine $\beta$-lipotropin by the solid-phase method. J. Am. Chem. Soc. 100: 5174-5179.

10. Li, C. H., D. Yamashiro, and S. Lemaire. 1975. Total synthesis of camel $\beta$-melanotropin by the solid-phase method. Biochemistry. 14: 953-956.

11. Lemaire, S., D. Yamashiro, A. J. Rao, and C. H. Li. 1977. Synthesis and biological activity of $\beta$-melanotropins and analogues. J. Med. Chem. 20: 155-158.

12. Li, C. H., D. Chung, D. Yamashiro, and C. Y. Lee. 1978. Isolation, characterization, and synthesis of a corticotropin inhibiting peptide from human pituitary glands. Proc. Natl. Acad. Sci. U. S. A. 75: 4306-4309.

13. Matsuoka, H., S. Y. Tan, and P. J. Mulrow. 1980. Effects of prostaglandins on adrenal steroidogenesis in the rat. Prostaglandins. 19: 291-298.

14. Fujita, K., G. Aguilera, and K. J. Catt. 1979. The role of cyclic AMP in aldosterone production by isolated zona glomerulosa cells. J. Biol. Chem. 254: 8567-8574.

15. Tan, S. Y., R. Noth, and P. J. Mulrow. 1978. Direct nonchromatographic radioimmunoassay of aldosterone: validation of a commercially available kit and observations on age-related changes in concentrations in plasma. Clin. Chem. 24: 1531-1533.

16. Gilman, A. G. 1970. A protein binding assay for adenosine $3^{\prime}: 5^{\prime}$-cyclic monophosphate. Proc. Natl. Acad. Sci. U. S. A. 67: 305-312.

17. Tovey, K. C., K. G. Oldham, and J. A. M. Whelan. 1974. A simple direct assay for cyclic AMP in plasma and other biological samples using an improved competitive protein binding technique. Clin. Chim. Acta. 56: 221-234.

18. Sen, S., E. L. Bravo, and F. M. Bumpus. 1977. Isolation of a hypertension-producing compound from normal human urine. Circ. Res. Suppl. 40: 5-10.
19. Sen, S., J. R. Shainoff, E. L. Bravo, and F. M. Bumpus. 1981. Isolation of aldosterone-stimulating factor (ASF) and its effect on rat adrenal glomerulosa cells in vitro. Hypertension (Dallas). 3: 4-10.

20. Sayers, G., R. L. Swallow, and N. D. Giordano. 1971. An improved technique for the preparation of isolated rat adrenal cells: a sensitive, accurate and specific method for the assay of ACTH. Endocrinology 88: 1063-1068.

21. Lowry, P. J., C. McMartin, and J. Peters. 1973. Properties of a simplified bioassay for adrenocorticotropic activity using the steroidogenic response of isolated adrenal cells. J. Endocrinol. 59: 43-55.

22. Bloomfield, G. A., A. P. Scott, P. J. Lowry, J. J. H. Gilkes, and L. H. Rees, 1974. A reappraisal of human $\beta-M S H$. Nature (Lond.). 252: 492-493.

23. Gilkes, J. J. H., G. A. Bloomfield, A. P. Scott, P. J. Lowry, J. G. Ratcliffe, J. Landon, and L. H. Rees. 1975. Development and validation of a radioimmunoassay for peptides related to $\beta$-melanocyte-stimulating hormone in human plasma: the lipotropins. J. Clin. Endocrinol. Metab. 40: 450-457.

24. Lowry, P. J., and A. P. Scott. 1975. The evolution of vertebrate corticotrophin and melanocyte stimulating hormone. Gen. Comp. Endocrinol. 26: 16-23.

25. Abe, K., W. E. Nicholson, G. W. Liddle, D. N. Orth, and D. P. Island. 1969. Normal and abnormal regulation of $\beta$-MSH in man. J. Clin. Invest. 48: 1580-1585.

26. Kastin, A. J., A. V. Schally, S. Viosca, and M. C. Miller. 1969. MSH activity in plasma and pituitaries of rats after various treatments. Endocrinology. 84: 20-27.

27. Dunn, J. D., A. J. Kastin, A. J. Carrillo, and A. V. Schally. 1972. Additional evidence for dissociation of melanocytestimulating hormone and corticotrophin release. J. Endocrinol. 55: 463-464.

28. Kastin, A. J., G. D. Beach, W. D. Hawley, J. W. Kendall, Jr., M. S. Edwards, and A. V. Schally. 1973. Dissociation of MSH and ACTH release in man. J. Clin. Endocrinol. Metab. 36: 770-772.

29. Hirata, Y., N. Sakamoto, S. Matsukura, and H. Imura. 1975. Plasma levels of $\beta$-MSH and ACTH during acute stresses and metyrapone administration in man. J. Clin. Endocrinol. Metab. 41: 1092-1097.

30. Howe, A., and A. J. Thody. 1970. The effect of ingestion of hypertonic saline on the melanocyte-stimulating hormone content and histology of the pars intermedia of the rat pituitary gland. J. Endocrinol. 46: 201-208.

31. Kobayashi, Y., and M. Takema. 1976. A morphometric study on the pars intermedia of the hypophysis during impairment of the renin-angiotensin-aldosterone system in sodium depleted mice. Cell Tissue Res. 168: 153-159.

32. Page, R. B., J. E. Boyd, and P. J. Mulrow. 1974. The effect of alpha-melanocyte stimulating hormone on aldosterone production in the rat. Endocr. Res. Commun. 1: $53-62$.

33. Vinson, G. P., B. J. Whitehouse, A. Dell, T. Etienne, and H. R. Morris. 1980. Characterization of an adrenal zona glomerulosa-stimulating component of posterior pituitary extracts as Alpha-MSH. Nature (Lond.). 284: 464-467.

34. Pedersen, R. C., A. C. Brownie, and N. Ling. 1980. Pro-adrenocorticotropin/endorphin-derived peptides: coordinate action on adrenal steroidogenesis. Science (Wash. D. C.). 208: 1044-1045.

35. Matsuoka, H., P. J. Mulrow, R. Franco-Saenz, and C. H. Li. 1980. Effects of $\beta$-lipotropin on aldosterone production in rats. Clin. Sci. (Lond.). 59(Suppl. 6): 91S-94S.

36. Wiedemann, E., T. Saito, J. A. Linfoot, and C. H. Li. 1977. 
Radioimmunoassay of human $\beta$-lipotropin in unextracted plasma. J. Clin. Endocrinol. Metab. 45: 1108-1111.

37. Krieger, D. T., A. S. Liotta, T. Suda, A. Goodgold, and E. Condon. 1979. Human plasma immunoreactive lipotropin and adrenocorticotropin in normal subjects and in patients with pituitary-adrenal disease. J. Clin. Endocrinol. Metab. 48: 566-571.

38. Lohmar, P., and C. H. Li. 1968. Biological properties of ovine $\beta$-lipotropic hormone. Endocrinology. 82: 898-904.

39. Lis, M., C. Gilardeau, and M. Chretien. 1972. Fat cell adenylate cyclase activation by sheep $\beta$-lipotropic hormone. Proc. Soc. Exp. Biol. Med. 139: 680-683.

40. Haynes, R. C., S. B. Koritz, and F. G. Peron. 1959. Influence of adenosine $3^{\prime}, 5^{\prime}$-monophosphate on corticoid production by rat adrenal glands. J. Biol. Chem. 234: 1421-1423.

41. Grahame-Smith, D. G., R. W. Butcher, R. L. Ney, and E. W. Sutherland. 1967. Adenosine 3',5'-monophosphate as the intracellular mediator of the action of adreno- corticotropic hormone on the adrenal cortex. J. Biol. Chem. 242: 5535-5541.

42. Beall, R. J., and G. Sayers. 1972. Isolated adrenal cells: steroidogenesis and cyclic AMP accumulation in response to ACTH. Arch. Biochem. Biophys. 148: 70-76.

43. Schimmer, B. P., and A. E. Zimmerman. 1976. Steroidogenesis and extracellular cAMP accumulation in adrenal tumor cell cultures. Mol. Cell. Endocr. 4: 263-270.

44. Lefkowitz, R. J., J. Roth, and I. Pastan. 1971. ACTHreceptor interaction in the adrenal: a model for the initial step in the action of hormones that stimulate adenyl cyclase. Ann. N. Y. Acad. Sci. 185: 195-209.

45. Seelig, S., G. Sayers, R. Schwyzer, and P. Schiller. 1971. Isolated adrenal cells: ACTH ${ }^{11-24}$, a competitive antagonist of ACTH ${ }^{1-39}$ and ACTH ${ }^{1-10}$. Febs (Fed. Eur. Biochem. Soc.) Lett. 19: 232-234.

46. Glossmann, H., A. Baukal, and K. J. Catt. 1974. Angiotensin II receptors in bovine adrenal cortex: modification of angiotensin II binding by guanylnucleotides. J. Biol. Chem. 249: 664-666. 